\title{
THE ORGANISII CAUSING THE DRY TOP ROT OF SUGAR CANE
}

\author{
Melville T. Coor, Plant Pathologist \\ Agricultural Experiment Station, Río Piedras, Puerto Rico.
}

This organism and the disease caused by it are very interesting because they were not known outside of Puerto Rico * for several years following their discovery and because of the problem involved in the taxonomy of the organism.

Matz (10) published the first description of the organism in 1920 under the name of Plasmodiophora vascularum. Two years later he published a second paper (11) in which he gave additional data.

Some doubt was expressed as to the taxonomic position of the organism which led the writer to make a study (1) which resulted in the transfer of the organism to the genus Ligniera. This was questioned by several workers and especially by Dr. W. R. Ivimey Cook of the University of Bristol, England, who started a correspondence with the author. Finally the author sent a collection of material to Dr. Cook of Bristol for study. As a result of these studies Dr. Cook decided that the disease was due to Rhizopods and prepared a paper (6) in which he described a new genus and two species, Amoebosperus vascularum and A. saccharinum. The writer disagreed with Dr. W. R. Ivimey Cook and immediately started a series of studies which have been continued to the present time. The results of these studies are recorded in this paper. In these studies the writer has examined a very large amount of material, fresh and in micro-preparations. All stages in the development of the organism are found without difficulty except the germination of the spores and the zoospore stages. However, sufficient material showing these stages was found to satisfy the writer that there is but one organism and that it does not belong to Plasmodiophora or to the Protozoa.

The organism passes into the new shoots of the cane as a plasmodium. This was demonstrated in fresh material from the field and in plants grown in pots in the green house and in water in glass cylinders in the laboratory. No stage other than the plasmodium

* It was found in Venezuela a few years ago. Probably introduced from Puerto Rico. 
was found in these young shoots and this plasmodium was always in the tracheary tubes. In the older canes it could be found in the other cells. The writer failed to find any nuclei in this plasmodium until the formation of the spores as described in the first paper (1). The nuclei appear with the formation of the spores (Figs. 1, 2 and 3 ) and have very much the same appearance as that stage of Woronina polycystis as figured by Cook and Nicholson in 1933 (8). These plasmodia in the older canes very frequently contain large bodies which the writer believes to be resting spores that have not germinated (Fig. 2). Dr. W. R. Ivimey Cook calls them empty cysts from which the spores have emerged. These resting spores or cysts can be found in great numbers and completely filling sections of the tracheary tubes. These large spores with very thick walls are to be found in the tracheary tubes (Figs. $8 \mathrm{x}$ ) and sometimes in the other cells (Figs. 8y and 16). The writer has observed large zoospores in those resting spores (Fig. 6, $a, b, c$ ) but has never observed the formation of a large number of spores in them as described by Dr. W. R. Ivimey Cook.

The writer has observed many spores which were variable in size and to some extent in form in both tracheary tubes and in the surrounding cells (Figs. 8-20). Spores that are fairly uniform in size and shape may occupy certain cells while in other cases the spores in a cell or tracheary tube may be variable in size.

The cells, other than these in the tracheary tubes that contain either plasmodia or spores develop very thick walls (Figs. 8, 10, 13, 15 and 16). These spores appear to be the same as those which W. R.' Ivimey Cook designated as cysts.

A careful study of the work of Matz, W. R. Ivimey Cook and the writer shows a very general agreement of some points but different interpretations. A comparison of all the studies by these three workers, including the data in this paper is as follows:

All have ageed that the organism lives in the fibro-vascular bundles. Matz states that it lives in the annular and spiral trachiedes and pitted vessels. The writer found the organism in the tracheary tubes, in the surrounding cells of the fibro-vascular bundle and sometimes in the parenchyma cells, especially in the older canes. In the very young canes it was confined to the tracheary tubes. W. R. Ivimey Cook reports $A$. vascularum in the spiral and annular tracheids and in the pitted vessels of the vaseular bundles, and $A$. saccharinum in some of the cortical cells as well as in the phloem and xylem parenchyma but never in the xylem vessels. 
Both Matz and the writer describe a plasmodium, while W. R. Ivimey Cook used the terms amoebae and amoeboid. Matz makes no mention of nuclei in the spores but his drawings show them. Both the Cooks state definitely that they failed to find nuclei in the spores. The writer has examined a large number of plasmodia (W. R. Ivimey Cook's amoeba) and failed to find any evidence of nuclei. However, as soon as the plasmodium begins to form spores the nuclei appear (Figs. 1 and 2).

Matz did not succeed in germinating the spores in sugar water, cane juice, in fermented cane juice or in several agars. The writer germinated many of the large spores, which W. R. Ivimey Cook called cysts in sterilized, distilled water.

The writer reported the formation of germ tubes in these old spores in his first paper but no evidence of swarm spores. In his later studies he found these resting spores or cysts could be geininated in sterilized distilled water. They were mounted in sterilized distilled water on slides and kept in moist chambers for one or more days. A few resting spores which had been kept in this manner showed a very slow internal movement as one large zoospore (Fig. $6 a$ and $6 b$ ) sometimes moving in one direction and sometimes in the other. In one case a cell wall had been formed and two moving bodies were observed (fig. $6 \mathrm{c}$ ), one in each cell. In another case three walls were formed indicating a quadrant (Fig. $6 d$ ) but there was no internal movement. These resting spores developed short germ tubes (Figs. $6 e$ and $7 a$ ) by which the zoospores emerged but the writer did not observe the emergence of them. However, many empty spores with open germ tubes and a few free swimming zoospores were observed. The zoospores rotated very slowly and in the same manner as those that were confined to the resting spores (Fig. $7 \dot{b}$ ). No cilia could be seen with a high power, oil immersion lens. Several of these zoospores were studied and found to develop a very slowly moving amoeboid form ( Fig $7 \mathrm{c}$ ). It is very evident to the writer that they represent this stage in the life history of the organism in the tracheary tubes of the host plant and that they unite to form the plasmodium. It is possible that zoospores in wet soil undergo the same transition. No nuclei were visible in this stage but the writer did not stain any of them.

A single flagellate spore was reported in the writer's first papci. It was in the tracheary tube in a prepared micro-section. No others have been observed by the writer. Dr. W. R. Ivimey Cook reported both amoeboid and flagellate stages. The writer did not 
observe the formation of a large number of spores such as were described by Dr. W. R. Ivimey Cook but the studies of the latter were necessarily confined to dead material. Therefore, it was impossible for him to make any studies on germination.

Very large resting spores (W. R. Ivimey Cook's cysts) with thick walls are to be found in the tracheary tubes, sometimes filling them for a considerable distance (Fig. $8 x$ ). They are sometimes found in other cells (Figs. $8 y$ and 16).

Matz reports that "sometimes these vessels were filled with a mass of granular protoplasm containing all stages between numerous, small, immature, ovate bodies of various sizes and the mature, spherical, larger spores". The writer found a variation in size and character of spores (Figs. 11 and 12) but believed them to be stages in the life history of a single organism. The results of the studies recorded in this paper support this opinion. Dr. W. R. Ivimey Cook believes them to be stages in the life history of the two different organism which he described. Matz does not mentioned nuclei in the spores but his drawings show them. Both Dr. W. R. Ivimey Cook and the writer found very definite nuclei.

The writer has observed many spores which were variable in size and to some extent in form in both tracheary tubes and in the surrounding cells (Figs. 8-20). Spores that are fairly uniform in size and shape may occupy certain cells while in other cases the spores in a cell or tracheary tube may be variable in size.

The spores, other than those in the tracheary tubes that contain either plasmodia or spores, develop very thick walls (Figs. 8, 10, 13, 15 and 16).

The plasmodia in the tracheary tubes and cells of other tissues had the same general appearance (Figs. 2 and 15). The large resting spores in the tracheary tubes and in other cells (Fig. 8) had the same general appearance and the writer does not believe that they were due to different organisms. Large and small spores were to be seen in the tracheary tubes (Figs. 10, 11, 12, 14 and 17) and in various other tissues (Figs. 10 and 13). The relationship of these large and small spores has not been established and the writer believes them to be stages of the one organism. If not, it is very evident that two parasites generally occupy the same cells at the same time.

W. R. Ivimey Cook writing of $A$. vascularum says:

"Germination of the spores is difficult to observe, and the author is not certain that the following stages form part of the same life-cycle. As far 
as he can see the spores germinate to produce a small spherical body containing a clearly marked nucleus in which there is a vacuole associated with the nucleus. The protoplasm late becomes more vacuolated as the amoeba grows."

In writing of $A$. saccharinum he says:

"The amoeba finally became surrounded with a cyst wall and the contents divided up into a number of small spherical cells each of which contained a single nucleus. . . . Fixation must have occurred during the process, since, while some of the spores, remain within the eyst, others have left it. As far as could be made out these bodies are provided with an apical flagellum, and at this early stage are pyriform in shape, though later they became rounded.',

Matz in his second paper discribed a division of spores into two, four and sometimes six parts. Dr. W. R. Ivimey Cook described a division in both his Amoebosporium saccharinum and his $A$. vascularum. The writer found a stage that appeared to be a division of the nuclei (Figs. 3 and 4) but failed to follow a life history such as that described by Dr. W. R. Ivimey Cook. Dr. W. R. Ivimey Cook also speaks of the protoplasm surrounding the empty eysts which is apparently the same as shown in figure 2. In my first paper on this subject I described this as a spore which had failed to germinate. Since that time I have examined a large number and am inclined to adher to that view. I have never found any of these spores with an opening in the wall, unless a germ tube had been formed.

Dr. W. R. Ivimey Cook speaks of the division of the nucleus in these large spores and the formation of a number of small spores. I have not been able to confirm his views in either case. The nuclei stain readily until the spores are almost mature (Fig. 5) but it is practically impossible to stain them in old resting spores (Figs. 2 and 8).

Dr. W. R. Ivimey Cook states that his Amoebosporum vascularum is found in the spiral, annular and pitted vessels of the vascular bundles and that his $A$. saccharinum is found in some of the cortical cells as well as in the phloem and xylem parenchyma, but never in the xylem vessels.

I have found what I believe to be one species in both tracheary tubes and in the fibrous cells (Figs. 14, 15, 16) and sometimes in the parenchyma. Also, I have found small spores in both tracheary tubes and in the fibrous cells (Figs. 9, 20). Sometimes I find both the large and small spores in the same tracheary tubes (Figs. 10-12) and the same in the fibrous cells (Figs. 18-20). I believe them to be stages in the life history of a single organism. I eannot harmonize Dr. W. R. Ivimey Cook's results with my studies on the germination of the large spores. However, it should be remembered that Dr. W. 
R. Ivimey Cook's studies have been restricted to the material which I sent to him while I had the advantage in that I studied fresh material throughout the year for several years.

One point which has not been mentioned in any of the previous papers is that when fibrous cells are inhabitated they always develop very thick walls, apparently the result of stimulation (Figs. 8-16).

Let us now turn our attention to the presence of this organism. or organisms in the roots. Thus far my studies on this phase of: the subject have been very limited but it is reasonable to suppose that the penetration is through the roots. This has not been observed but I have found the plasmodium in the roots, and Matz and the writer have found the spore stage.

\section{Method of Infection}

The method by which healthy plants become infected with this organism has not been definitely determined. Judging from the environmental conditions under which infections take place, the life history of the organism as traced in this paper and the life history of other organisms belonging to the Plasmodiophoraceae we are justified in believing that zoospores are formed and that they penetrate the roots of healthy canes. This has not been observed but Matz reported the finding of the organism in the roots of growing cane and the writer has found both the plasmodium and spores in the tracheary tubes of the roots.

\section{The Taxonomic Position of the Fungus}

The taxonomic relationship of this organism presents some rather interesting questions. My recent studies convince me that it does not belong to the Plasmodiophora or the Protozoa. It does not show nuclei in the plasmodium by any of the methods used. It is found mostly in the tracheary tubes and it does not cause hypertrophies.

It differs from the genus Sorosporaera in that it is not restricted to the roots but is most prominent in the stems and the spores are not collected into hollow masses.

It differs from the original description of the genus Ligniera in that it is not restricted to the roots but is most prominent in the stems but it resembles this genus in that it does not produce hypertrophies and in having the spores collected in masses.

The writer has made a careful study of the literature beginning with 1911 when Maire and Tison (12) erected the genus Ligniera. They said: 
"The difference between the swellings produced by Plasmodiophora Brassicae and those produced by Sorosphaera Veronicae is that the cells of Veronica show towards the end some mitosis that are not accompanied with cell wall formation, while in the case of cabbage the formation of cell walls follows the mitosis to the end.

"The study of Ligniera throws a new light on the affinities of the Plasmodiophoraceae. The Ligniera are very similar to the Rhizomyxa hypogae Borzi, also a non hypertrophiating parasite of the roots of various plants. That Rhizomyxa, according to Borzi, (1884) is a complex of various organisms and certainly the Ligniera were included in the complex. One of the drawings of Borzi represents $L$. verrucosa (that apparently grows on Trifolium resupinatum); other drawings suggest $L$. radicalis and $L$. junci. However, the real Rhizomyxa hypogae within the narrow limits given by A. Fischer (1892), characterized by the presence of zoospores within the thin walls containing several zoospores, such zoospores are not present in the Ligniera. The Ligniera are similar to the Toronina polycytis Cornu, whose balls of kystes remind one of the balls of spores of the L. verrucosa. It is quite possible that the Ligniera are derived from organisms similar to the Woronina through the disappearance of the zoosporocytes. The original of the Plasmodiophoraceae might be looked for in the studies of the Chytridiales.

"Nemec (1911) just described a Chytridiales of the Woroniaceae group, the Sorolpidium Beta, (13), parasites on the roots of Beta. That Chytridiales show plasmodia similar to those of the Ligniera, real zoosporocytes very similar to those of the Rhizomyxa. One can observe mitoses of a type similar to those of Plasmodiophoraceae. The author confirms our opinion as to the origin of the Plasmodiopraceae. They seem to be different from the Woroniaceae through the disappearance of the zoosporocytes."

Maire and Tison included in this genus two species which they had described, L. verrucosa living in the roots of Voronica arvensis and $L$. radicolis living in the roots of Callitriche stagnalis. They also transferred Sporosphora junci to this genus because it caused little or no hypertrophy of the roots and because the spores were not arranged in any definite system. In the following year Winge (1912) transferred Sorosphaera graminis to this genus.

Schwartz. (1914) published a paper (16) on the Plasmodiophoraceae and their relationship to Mycetozoa and Chytriadiae in which he recognized seven genera as follows; 1. Plasmodiophora, 2. Sorosphaera, 3. Tetramyxa, 4. Sorodiscus, 5. Molliardia, 6. Spongosporu and 7. Ligniera. The first five cause hypertrophies; the last two do not, In plasmodiophora the spores are free: in Sorosphciera they are collected into hollow spheres; in Ligniera they are collected into masses of varying shapes (e. g. spheres and ellipsoides).

In his discussion of the genus Ligniera he says,-

"The genus which is closely allied to Sorosphaera, was formed by Maire and Tison to include these members of the Plasmodiophoraceae in which the spore 
clusters are most usually ellipsoidal and irregular shaped and rarely spherical. A common characteristic of the members of this genus is that they do not give rise either to hypertrophy of tissue or to nuclear degeneration in the host plant."

He also says that all the species of this genus are root parasites living in the outer cortex and that the infection is through the root hairs.

W. R. Ivimey Cook (1926) published a paper on the genus Ligniera (2) in which he repeated the description of the genus as given by Maire and Tison which is as follows:

"In cellulis hospitis immutatis parasitans: nec tumores gignons; schizogina reducta; sporae in acervales variforme conjunctae.",

\section{He says,-}

"The full grown amoeba may be compared with the plasmodium of the Mycetozoa, which it resembles very closely. The size of the full-grown amoeba is usually limited by the size of the host cell, though if this cell is very large the contents may become exhausted before the amoeba has completely filled it.",

\section{In the summary of this paper he says,-}

"The genus Ligniera is a member of the plasmodiophoraceae, and has many points of relationship with the Mycetozoa. It differs from any other member of the group in not causing any hypertrophy of the host tissue.",

In 1928 Dr. W. R. Ivimey Cook (3) published a paper on the Methods of Nuclear Division in the Plasmodiophorales in which he said,-

"The Plasmodiophorales show a great similarity to the Amoeba in their methods of nuclear division. They show some similarity to the Mycetozoa in their life-history. It is considered probable that the two groups have originated from a common ancestor in the evolutionary series from Protomyxa to the Lobosa. Owing the presence of Protomitosis it is considered that the Plasmodiophorales have become separated before the Mycetozoa were. There is no common grounds for considering that the Plasmodiophorales and Chytridiales are closely related; the position of the Soroledipium betae does not support such an assumption.',

Cook and Schewartz (1929) in their paper (4) on Sorosphaera radicale said,-

" These zoospores however, bear a close resemblance to those previously observed in Ligniera junci and those described by other workers in the genera Spongospora and Plasmodiophora.

"It is the structure of the spore mass which renders this species easily distinguished from any previously described. In $L$. junci and $L$. verrucosa which have been known to attack grass roots the spores are not arranged in 
any definite system, though at times they appear to be grouped in a more or less spherical mass. In the genus Sorosphaera, of which only $S$. verronicae has been described, the spores are arranged, in a hollow sphere."

W. R. Ivimey Cook (1930) in a paper (5) on Plasmodiophora brassicae referred to the transfer of this species from Plasmodiophora to Ligniera by the writer of this paper and said,-

"Cook prefers to place the organism in the genus Ligniera, because it does not cause hypertrophy of the host tissues, but in our opinion (based on the two accounts which we have read) there is very little ground on which to refer it to either genus.',

W. R. Ivimey Cook (1933) published "A monograph of the "Plasmodiophorales", (7) in which he recognizes six genera: Plasmodiophora, (2) Sorosphaera, (3) Sorodiscus, (4) Spongospora, (5) Tetramyxa and (6) Ligniera. In his key the first five form a group and Ligniera is separated but in his diagram showing the phylogeny it is placed as an offshoot or branch of Plasmodiophora. In his discussion of this genus he says that Fitzpatrick "fails to recognize the difference between the genera Ligniera and Sorosphaera."

W. R. Ivimey Cook and E. J. Schwarts (1929) published a paper (4) on a new species, Sorosphaera radicale in which they said,-

"This new species seems to indicate that there is a definite relationship between the genus Sorosphaera and the genus Ligniera, and that hypertrophy is not a feature upon which too much importance must be based. Despite the comparatively close affinity between the two genera, it is a matter of very great difficulty to determine which of the two should be considered the more primitive. If, as has been pointed out before, spore systems are considered more advanced than scattered spores then Sorosphaera has been evolved from Ligniera."

Fitzpatrick (1930) (9) recognized but five genera: (1) Plasmodiophora, (2) Tetramyxa, (3) Sorosphaera, (4) Sorodiscus and (5) Spongospora. In Plasmodiophora the spores at maturity are not united and are free in the host cells. In Sorosphaera the spores are united into more or less definite spore balls which are spherical to ellipsoidal, hollow and consisting of a peripheral layer of spores enclosing a central cavity. He refused to recognize the genus Ligniera with the following statement,-

"As the genus Ligniera Maire \& Tison was based merely on a host reaction the writer is wholly disinclined to accept it as valid. It is clear that two hosts may react quite differently to a given parasite, one being stimulated to gall formation, while the other is not. It seems best for the present to include all the species in Sorosphaera, even though in some the tendency to form definite spore balls is much less evident than in the type species S. veronicae Schröter." 
A recent paper on this subject is the Taxonomy of the Plasmodiophoraceae by Palm and Burk (14). Their conclusions are based largely on a species of Sorosphaera on Veronica americana collected in Colorado. This species showed characters of Sorosphaera, Sorodiscus, Ligniera, Clathresorus and Spongospora. As a result of the studies they have suggested that Spongospora, Ligniera, Sorodiscus, Ostenfoldiolla, Clathresorus and Membranosorus should be made synonyms of Sorosphaera. The careful review that they have made of the subject appears to justify their suggestions. The writer is very much in sympathy with the suggestion. The organism under consideration does not fit exactly into any of the genera of Plasmodiophoraceae but it would fit into a genus Sorosphaera made to include the genera as suggested by Palm and Burk. The writer is of the opinion that this organism should be kept in the genus Ligniera or that there should be a merging of genera as suggested by Palm and Burk in which it would become Sorosphaera vascularum.

\section{ECONOMic Importance}

These studies have not given us as much data on this phase of the subject as we expected owing to the fact that we have not had the facilities for pursuing this phase of the work. All of the studies recorded in this paper have been made at the Experiment Station. Our knowledge of this phase of the subject may be summarized as follows,-

(1) It is more severe on some varieties than on others. It was very severe on D-109, a variety which is no longer in use on the island. It stopped the distribution of P. R. 801, a very promising: new variety. Our knowledge of its relationship to other varieties is very meager.

A recent outbreak of the disease on first ratoon of FC 1017 showed an infection of about 20 per cent. This cane was growing in irrigated Vega Baja silt loam which is rather difficult to drain and there had been a heavy rainfall over a considerable period of time. The same variety growing in easily drained soil did not show any symptoms of the disease although it is possible that there may have been some infection.

(2) It is most severe in poorly drained soils. A variety that is severely attacked by this organism under these conditions may thrive in well drained soil. The cane growing in low areas in a field may be severely damaged by this fungus while the surrounding cane of 
the same variety, but growing on higher land, may appear perfectly healthy. Cane growing on the higher levels may appear to be perfectly healthy but a careful examination may reveal the organism in some of the plants. On at least two occasions we have found that the cane in severely infected plantings was grown from cuttings that came from apparently healthy cane on well drained soil which upon examination showed the organism.

(3) The most important method of distribution from place to place is in the seed cuttings. It undoubtedly travels through wet soil from diseased to healthy plants, probably by zoospores which penetrate the roots.

\section{Literature Cited}

1. Cook, Melville T. Life History of Ligniera vascularum (Matz) Cook. Journ. of the Dept. of Agriculture of Porto Rico. 13: 19-29. 1929.

2. Cook, W. R. Ivimey. The Genus Ligniera Maire \& Tison. Trans. Brit. Mycol. Soc. 11(3-4) : 196-213. 1926.

3. The Methods of Nuclear Division in the Plasmodiophorales. Ann. Bot. 42:105-108. 1928.

4. Cook, W. R. Ivimey \& Schwartz, E. J. The Life-History of Sorosphaera radicale sp. nov. Ann. Bot. 43:81-88. 1929.

5. Cook, W. R. Ivimey, The Life-history, Cytology and Methods of Infection of Plasmodiophora brassicae Worn.; the Cause of Finger and Toe Disease of Cabbage and other Crucifers. Phill. Trans. of the Royal Society of London. Series B, Vol. 218:283-314, 1930.

6. - On the Life History and Systematic Position of the Organism causing Dry Top Rot of Sugar Cane. The Journ. of the Dept. of Agriculture of Puerto Rico. 16:409-418. 1932.

7. - A monograph of the Plasmodiophorales. Archiv fur Protistenkunde. 80 Band, Heft 2: 179-254. 1933.

8. Cook, W. R. Ivimey \& Nicholson, W. H. A Contribution to our knowledge of Wornina polycystis Cornu. Ann. Botany 47:851859. 1933 .

9. Fitzpatrick, H. MI. The Lower Fungi, Phycomyetes. 1930.

10. Matz, J. A new Vascular Organism in Sugar Cane. Journ. Dept. Agric. of Puerto Rico. 4:41-46. 1920.

11. - Dry Top of Sugar Cane. Journ. Dept. Agric. of Porto Rico. $6: 28-47.1922$.

12. Maire, $\boldsymbol{R}$. \& Tison, A. Nouvelles recherches sur les Plasmodiophoracies. Ann. Mycol. 9:226-246. 1911. 
96 THE JOURNAL OF AGRICULTURE OF THE UNIVERSITY OF P. R.

13. Nemec, B. Zur Kenntris der niederen Pilze. I. Eine neue Chytridiazee. Bull. Internat. de l'Academie des Sciences de Boheme. $1911: 1-19$.

14. Palm B. T. \& Burk, Myrle. The Taxonomy of the Plasmodiophoraceae. Arch. fur Protistenunde. 79. Band, Heft 2:263-276. 1933.

15. Schwartz, E. J. Root Diseases of Juncaceae. Ann. Bot. 24:511-522. 1910.

16. The Plasmodiophoraceae and their Relationship to the Mycetozoa and the Chytrideae. Ann. Bot. 28:227-240. 1914. 


\section{Explanation of Figures}

1. Transition from plasmodium to spores. Nuclei appear with the formation of spores. $(1 b)$.

2. Same. One old spore which did not germinate. The tracheary tube was cut oblique.

3. Cross section of tracheary tube showing formation of spores, one large spore which did not germinate, a spore with there nuclei which may indicate the formation of a quadrate, and surplus protoplasm.

4. Spore formation showing formation of quadrates.

5. Three large spores approaching maturity but both nuclei and inner bodies take the stain.

6. Three large spores kept in distilled water for 24 hours. The contents was moving rapidly, $a$. in one direction, $b$. in the opposite, c. showed a cell division and the contents of both halves were moving, $d$. showed three cell, was apparently a quadrate division, but there was no movement of the contents.

7. Germination of the resting spores by the formation of germ tubes and the transition of the zoospores into amoeboid stages.

8. The tracheary tubes and surroundings cells. Note the large spores in the tracheary tubes and in some of the small cells.

9. Two tracheary tubes. Note large spores in one and small spores in the other. Also small spores in small cells.

10. Tracheary tube surrounded by small cells. Note large and small spores in tracheary tube and small spores in surrounding cells.

11. Large and small spores in a tracheary tube.

12. Tracheary tube with large and small spores.

13. Part of tracheary tube and small cells. Both filled with small spores.

14. Two cells among fibrous cells, one with large and one with small spores. Note the thick walls.

15. Three cells among fibrous cells, one with plasmodium and two small spores. Note thick walls.

16. Small cells among fibrous cells, containing large spores. Note thick walls.

17. Three types of spores. The three large spores from one tracheary tube. The small spores of two sizes from another.

18, 19, 20. Large and small spores. Each group from a different tracheary tube. 


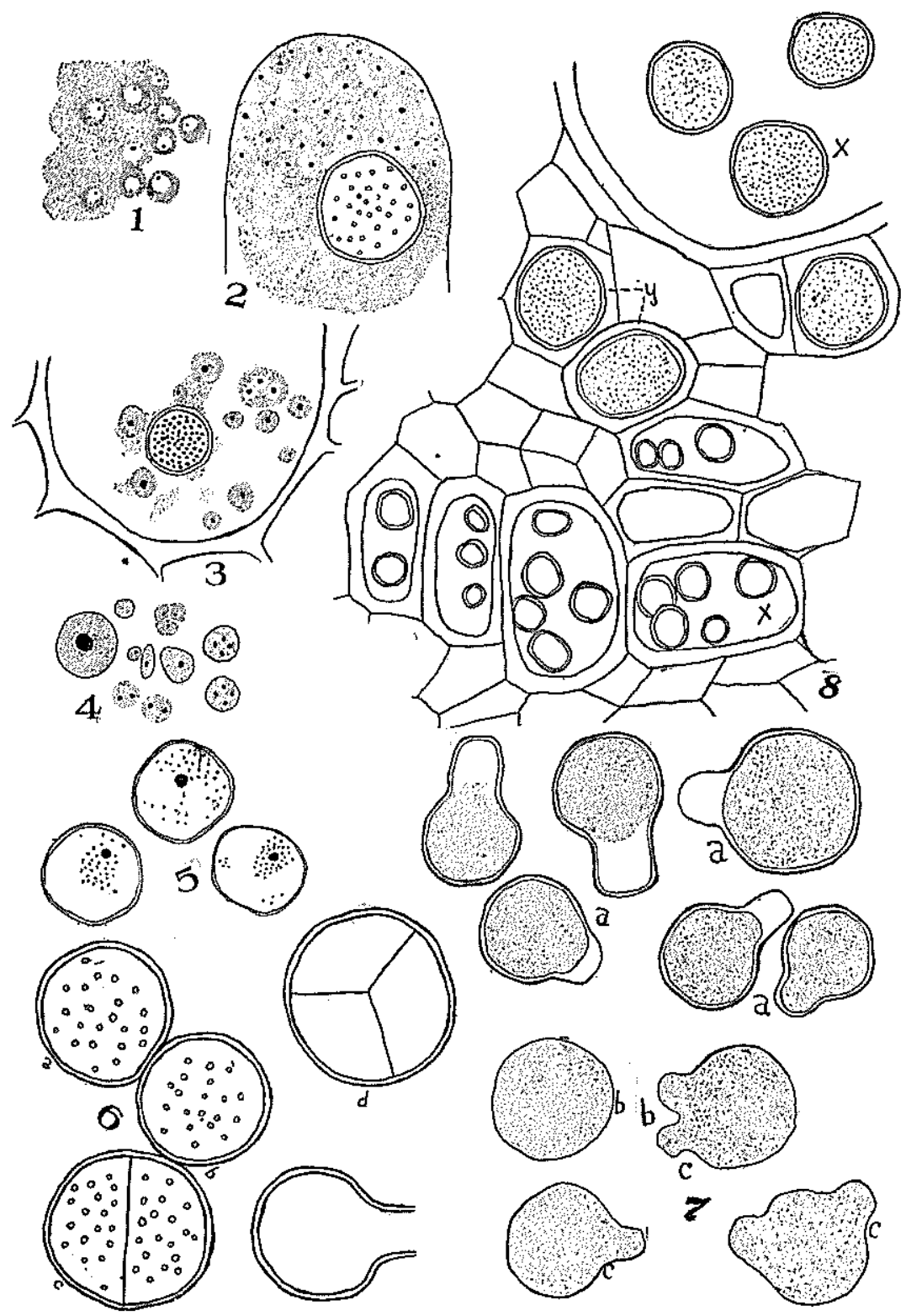




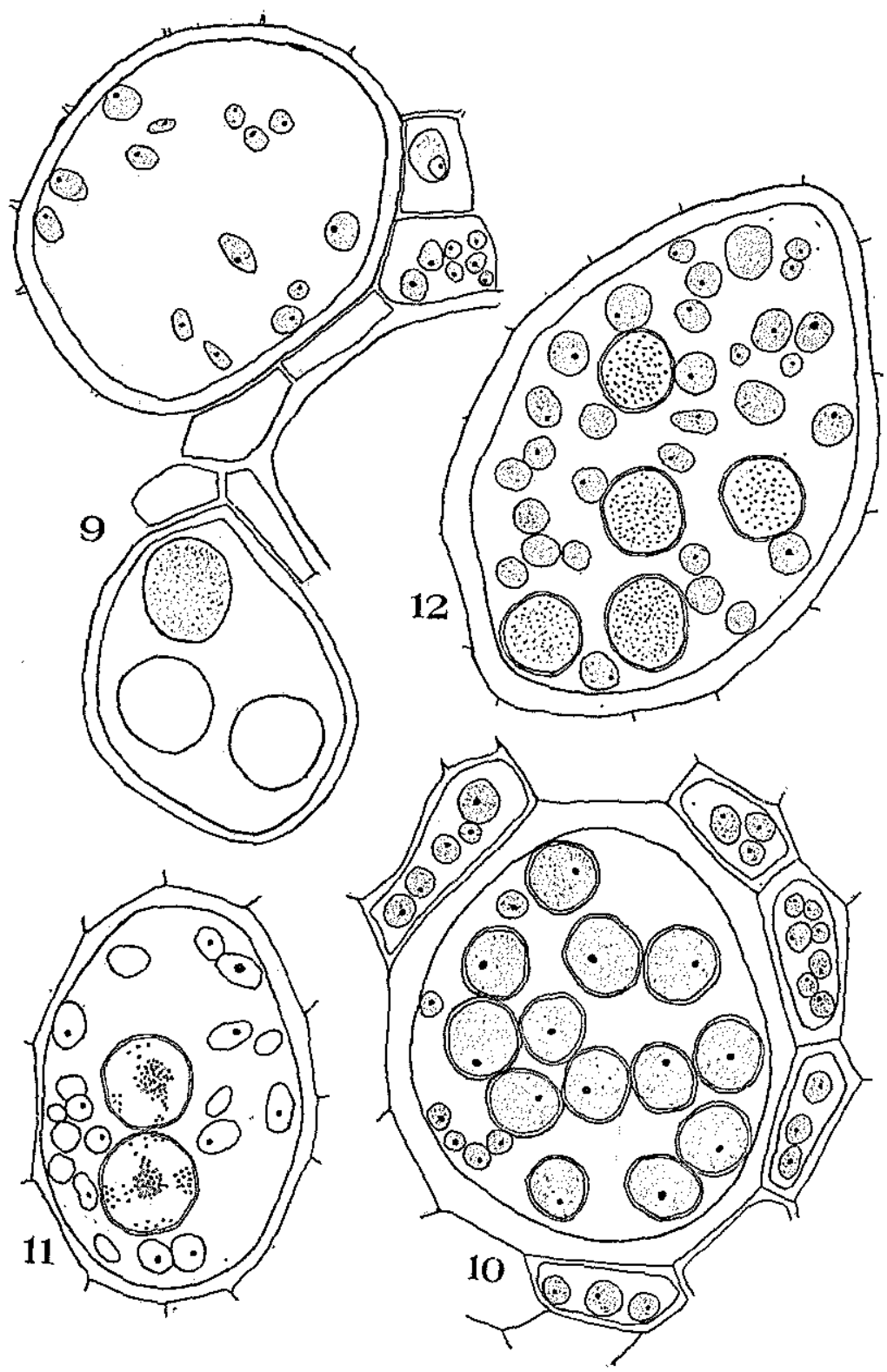



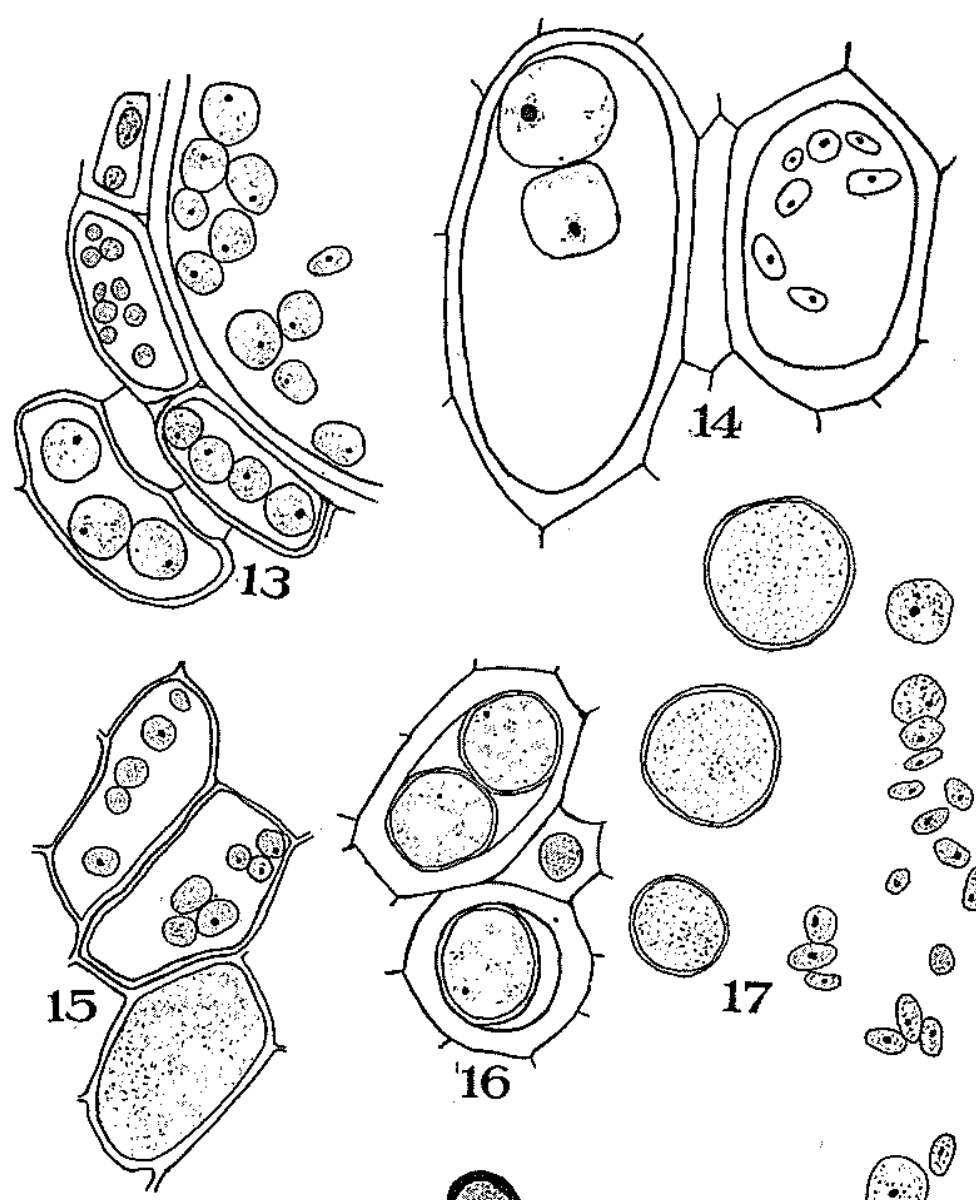

0

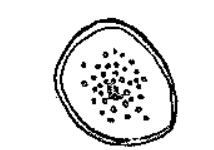

(-) 0

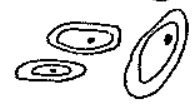

\section{8}

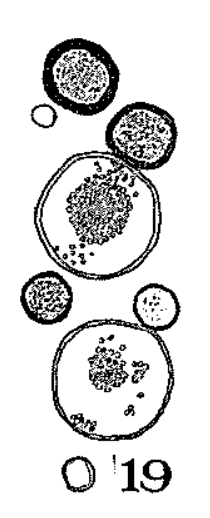

$0^{2}$

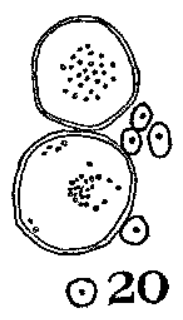

